Vol 11, Issue 10, 2018

\title{
IDENTIFICATION OF BIOACTIVE COMPONENTS IN ENHALUS ACOROIDES SEAGRASS EXTRACT BY GAS CHROMATOGRAPHY-MASS SPECTROMETRY
}

\author{
AMUDHA P, JAYALAKSHMI M, PUSHPABHARATHI N, VANITHA V* \\ Department of Biochemistry, School of Life Sciences, Vels University, Pallavaram, Chennai, Tamil Nadu, India. \\ Email: vanitha.sls@velsuniv.ac.in
}

Received: 01 March 2017, Revised and Accepted: 20 June 2018

\section{ABSTRACT}

Objective: This study deals with the determination of possible phytocompounds present in the ethyl acetate extract of Enhalus acoroides using gas chromatography-mass spectroscopy (GC-MS) technique.

Methods: Using GC-MS technique the phytocompounds present in the ethyl acetate extract of E. acoroides whole seagrass was investigated, and the mass spectra of the compounds found in the extract were matched with the National Institute of Standards and Technology library.

Results: GC-MS analysis of E. acoroides extract revealed the existence of several phytocompounds which includes 1-nonadecene (17.15\%), n-tetracosanol-1 (11.48\%), 1-octadecene (10.06\%), 2-pentadecanone (7.87\%), behenyl alcohol (7.33\%), 17-pentatriacontene (4.84\%), triacontane (4.25\%), tetratetracontane (4.17\%), and butylated hydroxytoluene (2.09\%).

Conclusion: E. acoroides possess distinct phytocompounds such as 1-nonadecene and n-tetracosanol-1 which possess antioxidant property, triacontane which has antibacterial, antidiabetic and antitumor activities. Further studies need to elute novel bioactive compounds and toxicity profile through animal models.

Keywords: Enhalus acoroides, Gas chromatography-mass spectroscopy, Phytocompounds, Biological activity, 1-Nonadecene, n-tetracosanol-1.

(C) 2018 The Authors. Published by Innovare Academic Sciences Pvt Ltd. This is an open access article under the CC BY license (http://creativecommons. org/licenses/by/4. 0/) DOI: http://dx.doi.org/10.22159/ajpcr.2018.v11i10.25577

\section{INTRODUCTION}

Traditional customs of practicing the medication plants is composed of skills and practical knowledge and also followed on theoretical knowledge, belief in treatment and various traditions which are practiced to maintain the physical fitness and also the medicinal plants help to prevent the diseases, diagnostic purposes or to cure physical, as well as mental illness [1]. Various kinds of medicinal plants used traditionally, and other herbal practices known as complementary or alternative medicine are nowadays implementing in developing countries and also in developed countries. World Health Organization has defined herbal plants possesses biological components which can be used for many medication purposes and also to synthesize secondary metabolites which can be used to produce essential drugs [2].

Nowadays, medication plants become more of importance in improving the analysis and quality control section along with many improvements in the field of clinical research have become prominent in treating various diseases [3]. Over the past century, the phytocompounds in herbs play an important role in pharmaceutical industries [4]. Phytochemicals are natural bioactive compounds seen in whole parts of the plants such as root, stem, bark, leaves, seed, and fruits. Many traditionally used plants are economically benefitted, for example, oils, resins, tannins, natural rubber, gums, waxes, dyes, pharmaceuticals, and pesticides [5].

Analytical techniques have shown a drastic improvement from the past decade such as thin-layer chromatography, ultraviolet, nuclear magnetic resonance, and GC-MS that were promising techniques for separation, identification, and structural determination of phytochemicals. GC-MS, a powerful tool and also a consistent technique and most commonly used the procedure for identification and quantification of phytochemicals. The unknown phytocompounds in a complex phytochemical mixture can also be determined by interpretation, and the spectrum was matched with the National Institute of Standards and Technology (NIST) [6].

Marine plants are a good source of nutraceuticals and potent drugs in curing many human diseases. Approximately $80 \%$ of the diverse plant as well as animal species are seen in oceans [7]. There are approximately 57 species of seagrass worldwide [8]. Enhalus acoroides L.C. Rich ex Steud, belonging to the monotypic marine genus Enhalus in the family Hydrocharitaceae is commonly seen in the coasts of Indian Ocean and also tropical parts of Western Pacific [9]. Gillan et al. showed that E. acoroides leaves contain sterol as well as fatty acid components. The crude extract of $E$. acoroides possesses scavenging free radicals since it contains active secondary metabolites such as phenolics, flavonoids, and tannins and this justified its uses in folkloric medicines [10]. However, the isolation and bioactivity of other secondary metabolites from E. acoroides are not reported [11]

Literature studies reveal that the information on secondary metabolites using GC-MS analysis of E. acoroides is inadequate. Hence, the current study is focussed on the dealing of phytocompounds present in ethyl acetate fraction of $E$. acoroides.

\section{METHODS [12]}

Collection and authentication of $E$. acoroides

The fully matured E. acoroides were taken from Devipattinam, Ramanathapuram District during the period of June 2016 and authenticated in ICAR by Dr. N. Kaliaperumal M.Sc., Ph.D., Scientist-incharge, CMFRI.

\section{Preparation of extracts}

The collected E. acoroides leaves washed with distilled water carefully to remove the traces of impurities. The leaves were shade dried, mechanically grinded and powdered. The grinded powder was initially 
soaked into 1:2 ratio ethyl acetate (semi-polar) for 3 days with mild shaking. After 3 days, the ethyl acetate was decanted, and the collected extract was stored at room temperature in a dark place, and the ethyl acetate solvent was evaporated. Finally, solid material was collected and stored at $4^{\circ} \mathrm{C}$ until used.

\section{GC-MS analysis [13]}

GC-MS analysis was carried out on GC-MS - 5975C (AGILENT) under the following conditions. DB- $5 \mathrm{~ms}$ Agilent $(30.0 \mathrm{~m} \times 0.25 \mathrm{~mm} \times 0.25 \mu \mathrm{m})$ was used. Using helium as carrier gas ( $99.9995 \%$ purity) at a constant flow rate of $1.51 \mathrm{~mL} / \mathrm{min}$ and an injection volume of $2 \mu \mathrm{L}$ was employed in a split mode. The injector temperature was maintained at $240^{\circ} \mathrm{C}$, and the column temperature was programmed to $70^{\circ} \mathrm{C}$ (isothermal for $2 \mathrm{~min}$ ) with increasing temperature of $10^{\circ} \mathrm{C} / \mathrm{min}$ to $300^{\circ} \mathrm{C}$ (isothermal for $9 \mathrm{~min}$ ). $200^{\circ} \mathrm{C}$ for ion source temperature and $240^{\circ} \mathrm{C}$ for interface

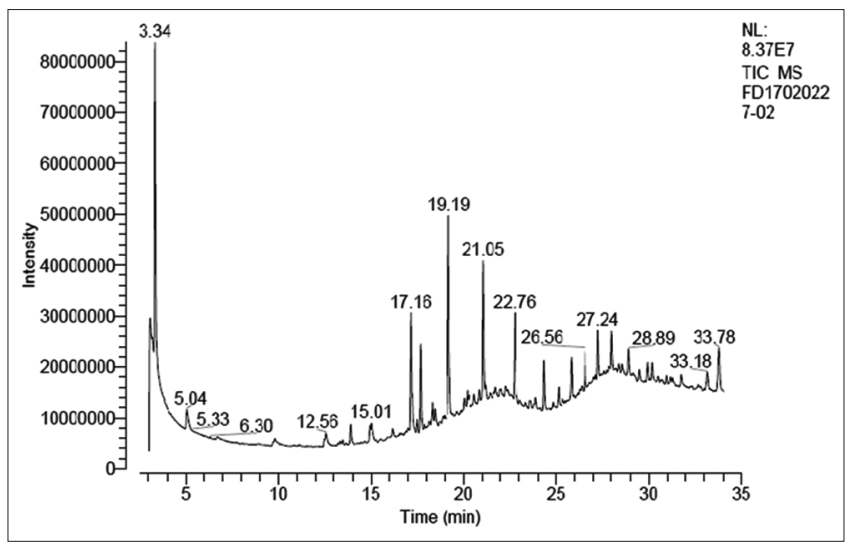

Fig. 1: Chromatogram of ethyl acetate extracts of Enhalus acoroides temperature were maintained. The mass spectra were obtained through ionization energy of $70 \mathrm{eV}$ in the EI mode. Total 30 min need to run GC-MS. The phytocompounds were identified by comparison of mass spectra with the national libraries (NIST - 11).

\section{Identification of components}

The phytocomponents present in the ethyl acetate extract was identified by comparing the spectrum with the database of National Institute of Standard and Technology (NIST) which has 62,000 patterns. The compound name, retention time, molecular formula, as well as structure were determined. Each components percentage of area was calculated by comparing its average peak area to the total areas. The unknown compounds spectrum was compared with the spectrum of the known compound stored in the NIST library.

\section{RESULTS AND DISCUSSION}

GC-MS is a technique which combines the properties of gas chromatography-mass spectrometry which identifies various substances within the test sample which includes hydrocarbons, alcohols, acids, esters, alkaloids, steroids, amino and nitro compounds, and so on [14]. GC-MS also helps to find the traces in materials. GC-MS has been commonly called as "gold standard" for forensic substance identification since it can be used to analyze a specific test $[15,16]$.

Nearly 30 phytocompounds were found in E. acoroides by GC-MS analysis. The active phytocompounds with their retention time, molecular formula, molecular weight, and concentration (\%) are presented in Table 1 and Fig. 1. The prevailing compounds were 1-nonadecene (17.15\%), n-tetracosanol-1 (11.48\%), 1-octadecene (10.06\%), 2-pentadecanone (7.87\%), behenyl alcohol (7.33\%), 17 -pentatriacontane $(4.84 \%)$, triacontane $(4.25 \%)$, tetratetracontane (4.17\%), and butylated hydroxytoluene (2.09\%). The biological functions of these phytocompounds were identified in the ethyl acetate extracts of the E. acoroides tabulated in Table 2.

Table 1: GC-MS analysis and mass spectral data of ethyl acetate fraction from the seagrass E. acoroides showing molecular formula, molecular weight, mass peak, retention time, and structure

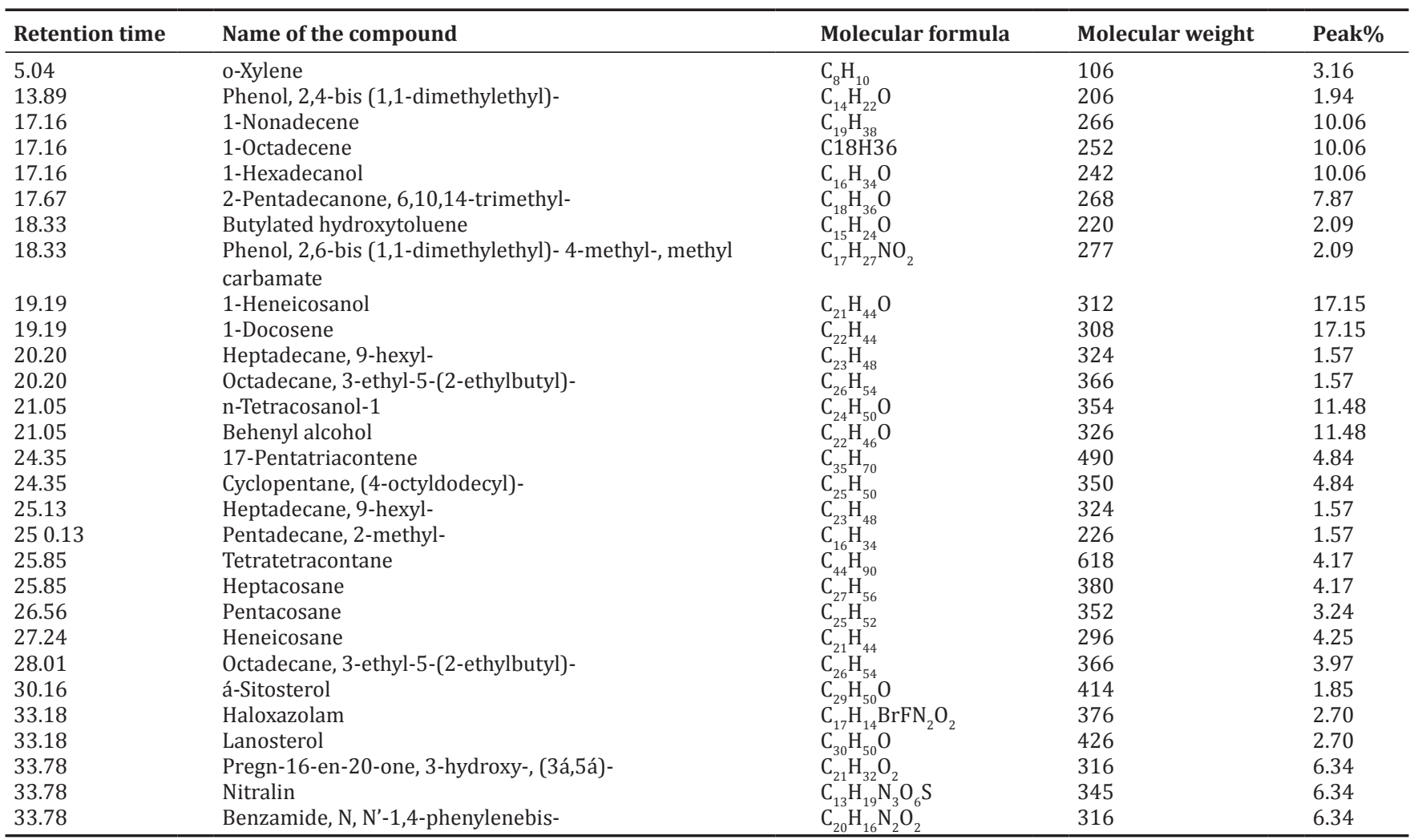

E. acoroides: Enhalus acoroides, GC-MS: Gas chromatography-mass spectroscopy 
Table 2: Bioactivity of phytocomponents identified in the ethyl acetate extracts of $E$. acoroides by GC-MS

\begin{tabular}{|c|c|c|}
\hline Name of the compound & $\begin{array}{l}\text { Structure of the } \\
\text { compound }\end{array}$ & Biological activities \\
\hline Phenol, 2,4-bis (1,1-dimethylethyl)- & & Antibacterial and anti-inflammatory [17] \\
\hline 1-Nonadecene & W & Antituberculosis, anticancer, antioxidant, antimicrobial $[18,19]$ \\
\hline $\begin{array}{l}\text { 1-Octadecene } \\
\text { 1-Hexadecanol }\end{array}$ & $\sim$ & $\begin{array}{l}\text { Not intended for a therapeutic purpose } \\
\text { Antioxidant [20] }\end{array}$ \\
\hline 2-Pentadecanone, 6,10,14-trimethyl- & & Hypocholesterolemic, antioxidant, and lubrication [21] \\
\hline Butylated hydroxytoluene & & Antioxidant [22] \\
\hline $\begin{array}{l}\text { Phenol, } \\
\text { 2,6-bis (1,1-dimethylethyl)-4-methylz, } \\
\text { methyl carbamate }\end{array}$ & & Treatment for Huntington's disease [23] \\
\hline $\begin{array}{l}\text { 1-Heneicosanol } \\
\text { Heptadecane, 9-hexyl- }\end{array}$ & m & $\begin{array}{l}\text { Antifungal [24] } \\
\text { Antifungal [25] }\end{array}$ \\
\hline Octadecane, 3-ethyl-5-(2-ethyl butyl)- & & Not intended for a therapeutic purpose \\
\hline $\begin{array}{l}\text { n-Tetracosanol-1 } \\
\text { Behenyl alcohol }\end{array}$ & m & $\begin{array}{l}\text { Antioxidant [26] } \\
\text { Hair conditioners moisturizers and lubricating oils [27] }\end{array}$ \\
\hline 17-Pentatriacontene & & Not intended for a therapeutic purpose \\
\hline Tetratetracontane & manmmms & Antioxidant and cytoprotective activities [28] \\
\hline Heptacosane & & Not intended for a therapeutic purpose \\
\hline Triacontane & MWWWwW & Antibacterial, antidiabetic, and antitumor activities [29] \\
\hline Heneicosane & wmw & Not intended for a therapeutic purpose \\
\hline Octadecane, 3-ethyl-5-(2-ethylbutyl)- & & Antimicrobial and antifungal agents [30] \\
\hline á-Sitosterol & & $\begin{array}{l}\text { Antimicrobial anticancer anti-inflammatory anti-asthma, and diuretic } \\
\text { antiarthritic [31] }\end{array}$ \\
\hline Haloxazolam & & Not intended for a therapeutic purpose \\
\hline Lanosterol & & Regulators of cholesterol biosynthesis [32] \\
\hline Pregn-16-en-20-one, 3-hydroxy-, (3á,5á)- & & Not intended for a therapeutic purpose \\
\hline
\end{tabular}

E. acoroides: Enhalus acoroides, GC-MS: Gas chromatography-mass spectroscopy

The most abundant phytocompounds identified in E. acoroides are 1-nonadecene (17.15\%) and n-tetracosanol-1 (11.48\%), respectively. 1-Nonadecene is long-chain fatty acids showed antituberculosis activity as well as antifungal activity, respectively. $\mathrm{n}$-Tetracosanol-1 is an alcoholic compound which possesses antibacterial activity [18]. 
Alam et al. [33] found antibacterial activity in methanol and hexane extracts of E. acoroides. 1- Hexadecanol, an alcoholic compound which showed antioxidant activity. Antioxidant safeguards the body from degenerative diseases [34] and the phytocomponent 2-pentadecanone, 6,10,14-trimethyl- which has hypocholesterolemic activity, antioxidant, and lubrication activity [21]. Butylated hydroxytoluene has antioxidant properties [22] and phenol-2,6-bis(1,1-dimethylethyl)-4, methyl carbamate could be used to synthesize phenol-4-[2-(aminomethyl)-4thiazolyl]-2,6- bis(1,1-dimethylethyl) monohydrochloride which can be used to treat Huntington's disease [23].

Phenol-2, 4-bis (1, 1-dimethylethyl), and cyclic compound are unsaturated and hence plays an important role in free radical scavenging. The unsaturation degree for cyclic compounds is greater and also a good antioxidant [35]

Heptadecane, 9- hexyl and Ethyl iso-allocholate are most effective plant extract which possesses antifungal activity. Tetratetracontane possesses antioxidant as well as cytoprotective activities. Heptadecane and octadecane, 3-ethyl-5-(2- ethyl butyl)- are effective antimicrobial and antifungal agents.

Steroid compounds are derived from lanosterol, a tetracyclic triterpenoid. One biological system that can be used to produce oxygenerated derivatives of cholesterol and lanosterol [36,37]. This proves that oxysterols may be natural regulators of cholesterol biosynthesis in the intact cell.

This paper reveals the goodness of E. acoroides which has various medicinal properties and can be highly commended as a plant of phytopharmaceutical importance. Based on the phytocomponents present, biological properties of earlier studies have been reported. Hence, E. acoroides can be used as an important medication plant in the folklore medicine.

\section{CONCLUSION}

The present study revealed that the ethyl acetate extract of $E$. acoroides of GC-MS analysis proves the presence of numerous active phytoconstituents responsible for various pharmacological activities and justifies the medicinal use of this plant in folklore medicine. According to the literature survey that we believe this is the first report of GC-MS analysis of seagrass extract. Hence, E. acoroides might be utilized for finding new drugs, and further investigation needs to elute novel bioactive compounds and toxicity profile through in vitro and in vivo models.

\section{AUTHOR'S CONTRIBUTION}

No author's contribution.

\section{CONFLICTS OF INTEREST}

The authors declare that there are no conflicts of interest regarding the publication of this article.

\section{REFERENCES}

1. Tapsell LC, Hemphill I, Cobial L. Health benefit of herbs and species. The past, the present, the future. Med J Austria 2006;188(4):4-24.

2. Amudha P, Bharathi NP, Vanitha V. Caesalpinia bonducella-a review on pharmacological and phytochemical activity of seeds. Int J Pharm Bio Sci 2016;7:674-80.

3. Tabacco E, Borreani G, Crovetto GM, Galassi G, Colombo D, Cavallarin L, et al. Effect of chestnut tannin on fermentation quality, proteolysis, and protein rumen degradability of alfalfa silage. J Dairy Sci 2006;89:4736-46.

4. Amudha P, Varadharaj V. Phytochemical and pharmacological potential of Annona species: A review. Asian J Pharm Clin Res 2017;10:1-8.

5. Christopher B. RHSA-Z Encylopedia of Garden Plants. $3^{\text {rd }}$ ed. London: Dorling Kindersley; 2003. p. 738-51.

6. Hites AR. Gas Chromatography Mass Spectroscopy: Handbook of Instrumental Techniques for Analytical Chemistry. New Jersey: Prentice Hall PTR; 1997. p. 609-11.
7. Jayalakshmi M, Amudha P, Vanitha V. Assessment of minerals from shrimp shell waste. Res Pharm Sci 2017;8:194-7.

8. Arsad A, Bujang JS, Zakaria MH. Distribution and Significance of Seagrass Ecosystems in Malaysia. Malaysia: Aquatic Ecosystem Health and Management Society; 2006. p. 203-14.

9. Hartog CD, Kuo J. Taxonomy and biogeography of seagrasses. In: Larkum AW, Orth RJ, Duarte CM, editors. Seagrass. Springer, Berlin: Biology, Ecology and Conservation; 2006. p. 691.

10. Amudha P, Vanitha V. Phytochemical analysis and in vitro antioxidant screening of sea grass-Enhalus acoroides. Int J Res Pharm Sci 2017;8:1-8.

11. Gillan FT, Hogg RW, Drew EA. The sterol and fatty acid compositions of seven tropical seagrasses from North Queensland, Australia. Phytochemistry 1984;23:2817-21.

12. Hemalatha S, Amudha P, Bharathi NP, Vanitha V. Determination of bioactive phytocomponents from hydroethanolic extract of Annona squamosa (Linn.) Leaf by Gc-Ms. Int J Pharm Sci Res 2017;8:2539-44.

13. Mathi P, Nikhil K, Das S, Roy P, Bokka VR, Botlagunta M. Evaluation of in vitro anticancer activity and GC-MS analysis from leaf Sophora Interrupta Bedd. Int J Pharm Pharm Sci 2015;7:303-8.

14. Saravanan $P$, Chandramohan G, Mariajancyrani J, Shanmugasundaram P. Gc-Ms analysis of phytochemical constituents in ethanolic bark extract of Ficus religiosa Linn. Int J Pharm Pharm Sci 2014;6:457-60.

15. Harbourne JB. Phytochemical Methods. A Guide to Modern Techniques of Plant Analysis. $2^{\text {nd }}$ ed. London: Chapman and Hall; 1984. p. 4-120.

16. Wagner H, Bladt S, Zgainski EM. Plant Drug Analysis. Berlin: Springer-Verlag; 1984. p. 298-334.

17. Amaral AC, Gomes LA, Sila JR, Ferreira JL, Ade SR, Mdo SR, et al. Liposomal formulation of turmerone-rich hexane fractions from Curcuma longa enhances their antileishmanial activity. Biomed Res Int 2014; doi: 10.1155/2014/694934.

18. Rukachaisirikul T, Siriwattanakit P, Sukcharoenphol K, Wongvein C, Ruttanaweang $\mathrm{P}$, Wongwattanavuch $\mathrm{P}$, et al. Chemical constituents and bioactivity of Piper sarmentosum. J Ethnopharmacol 2004;93:173-6.

19. Lee YS, Kang MH, Cho SY, Jeong CS. Effects of constituents of Amomum xanthioides on gastritis in rats and on growth of gastric cancer cells. Arch Pharm Res 2007;30:436-43.

20. Mishra PM. Sree A. Antibacterial activity and GC-MS analysis of the extract of leaves of Finlaysonia obovata (A mangrove plant). Asian J Plant Sci 2007;6:168-72.

21. Kumar PP, Kumaravel S, Lalitha C. Screening of antioxidant activity, total phenolics and GC-MS study of Vitex negundo. Afr J Biochem 2010;4:191-5

22. Yehye WA, Rahman NA, Ariffin A, Hamid SB, Alhadi AA, Kadir FA, et al. Understanding the chemistry behind the antioxidant activities of butylated hydroxytoluene (BHT): A review. Eur J Med Chem 2015; 101:295-312

23. Committee for Orphan Medicinal Products. Public Summary of Opinion of Orphgan designation. Phenol, 4- (2-(amino methyl)-4- thiazoyl)-2, 6-bis (1,1- dimethylethyl) Monohydrochloride for the Treatment of Huntington's Disease; 2015

24. Arancibia LA, Naspi CV, Pucci GN, Arce ME.,Colloca CB. Biological activity of 1-heneicosanol isolated from Senecio coluhuapiensis, an endemic species from Patagonia. Pharm Chem J 2016;3:73-7.

25. Abubacker MN, Devi PK. In vitro antifungal potentials of bioactive compounds heptadecane, 9- hexyl and Ethyl iso-allocholate isolated from Lepidagathis cristata Wild. (Acanthaceae) leaf. BBB 2015;3:336-43.

26. Lakshmi M, Nair BR. GC-MS analysis of the chloroform extract of bark of Terminalia travancorensi Wight and Arn. (Combretaceae). Int J Pharm Sci Res 2017;8:794-8.

27. Ertas A, Yilmaz MA, Firat M. Chemical profile by LC-MS/MS, GC/MS and antioxidant activities of the essential oils and crude extracts of two euphorbia species. Nat Prod Res 2015;29:529-34.

28. Mallick SS, Dighe VV. Detection and estimation of alpha-amyrin, beta-sitosterol, lupeol and n-tricontane in two medicinal plants by high performance thin layer chromatography. Adv Chem 2014; doi. org $/ 10.1155 / 2014 / 143948$.

29. Mammen D, Daniel M, Sane RT. Seasonal and geographical variations in chemical constituents of Leptadenia reticulate. Int J Pharm Sci Rev Res 2010;4:111-6.

30. Rao MR, Phillips S, Kumar MH, Saranya Y, Divya D, Prabhu K. GC-MS analysis, antimicrobial, antioxidant activity of an ayurvedic medicine, Salmali niryasa. J Chem Pharm Res 2015;7:131-9.

31. Jegajeevanram P, Alhaji NM, Kumarave S. Identification of pesticide compounds of Cynodon dactylon by GC-MS analysis. Int J Pharm Bio Sci 2014;5:604-8. 
32. Kandutsch AA, Chen HW, Heiniger HJ. Biological activity of some oxygenated sterols. Science 1978;201:498-501.

33. Alam MS, Chopra N, Ali M. Niwa M. Oleanen and stigmasterol derivatives from Ambroma augusta. Phytochemistry 1996;41:1197-200.

34. Chandramohan A, Divya RS. Comparison of antioxidant activity in Gracilaria edulis and Hypnea valentiae. IJARIIT 2017;3:294-6.

35. Prakash A, Suneetha V. Punica granatum (Pomegranate) rind extract as a potent substitute for L- ascorbic acid with respect to the antioxidant activity. Res J Pharm Biol Chem Sci 2014:5:597.

36. Nelson JA, Steckbeck SR, Spencer TA. Biosynthesis of 24,25-epoxycholesterol from squalene 2,3;22,23-dioxide. J Biol Chem 1981;256:1067-8.

37. Panini SR, Sexto RC, Rudney H. Regulation of 3-hydroxy-3-methylglutaryl coenzyme A reductase by oxysterol by-products of cholesterol biosynthesis. Possible mediators of low density lipoprotein action. J Biol Chem 1984;259:7767-71 